\title{
The Effectiveness of Teaching Formulaic Politeness Strategies in Making Request to Undergraduates in an ESL Classroom
}

\author{
Kim Hua $\operatorname{Tan}^{1} \&$ Atieh Farashaiyan ${ }^{1}$ \\ ${ }^{1}$ School of Language Studies and Linguistics, Universiti Kebangsaan Malaysia, 43600 Bangi, Selangor, \\ Malaysia \\ Correspondence: Atieh Farashaiyan, School of Language Studies and Linguistics, Universiti Kebangsaan \\ Malaysia, 43600. Tel: 60-17-305-8184. E-mail: Atieh_Farashaiyan@yahoo.com
}

Received: November 15, 2012 Accepted: November 19, 2012 Online Published: November 30, 2012

doi:10.5539/ass.v8n15p189

URL: http://dx.doi.org/10.5539/ass.v8n15p189

\begin{abstract}
It is widely acknowledged that the main thrust of second language (L2) teaching and learning is establishing and developing the communicative competence of learners. Especially, in recent years, the focus has shifted more towards intercultural communicative competence (ICC). As such, it is more practical that educational endeavors should be directed both towards the grammar or lexis of the target language as well as the appropriate use of these grammatical and lexical systems in a variety of situations by considering different social and contextual factors. Therefore, this study embarks on the effect of explicit instruction of formulaic politeness strategies among Malaysian undergraduates in making request. Sixty Malaysian undergraduates participated in the study. The students included two groups of intervention and control groups. The data were cumulated through three tests, namely open ended completion test, a listening test and an acceptability judgment test. Treatment or experimental group received explicit instruction with structured and problem-solving and input tasks. The comparison was made between the performance of treatment group and that of control in terms of the pre-test and post-test. The findings show that the treatment group outperformed significantly than the control group. This matter is suggestive that in this probe, explicit form-based instruction was successful for learners to comprehend and produce the English politeness strategies effectively in making request. The findings of this study will be beneficial for material developers and teachers to make use of form-focused strategies more effectively to teach second language pragmatic features to Malaysian students.
\end{abstract}

Keywords: formulaic politeness strategies, form-focused instruction, downtoners, downgraders, undergraduates

\section{Introduction}

The widely accepted view is that the primary goal of Second Language(L2) instruction is establishing and developing the communicative competence of learners and one of its most vital components, that is pragmatic competence ( Bachman, 1990; Celce-Murcia, Dörnyei and Thurrell,1995; Usó-Juan and Martínez-Flor, 2006). Pragmatic competence is recognized as the ability of learners to make use of a variety of linguistic formula appropriately when communicating in a context that is socially and culturally specific. For this end, learners are required to master both types of pragmatic competence; pragmalinguistics dealing with the resources/ linguistics realizations for conveying specific communicative or speech acts and sociopragmatics dealing with the appropriate use of those linguistic forms/realizations be learners based on the context, the special roles of the participants in that context and the politeness factors of social distance, power, and the degree of imposition ( Brown \& Levinson, 1978; 1987).

Request as one of the most important speech acts studies in L2 pragmatic studies has attracted the scholars' attention in L2 pragmatics research. Request is deemed as one of the speech acts frequently utilized in human interactions for information or cooperation from others. It is highly important to L2 learners because most of their L2 interactions take place in the form of requests (Fraser, 1980; Fraser, Rintell \& Walters, 1980; Koike, 1989).

Moreover, with regard to the categorization of illocutionary acts by Searle (1969), (i.e. representatives, directives, expressives, commissives, and declarations), requests are considered as directives, which have been defined as "an attempt to get hearer to do an act which the speaker wants the hearer to do, and which it is not obvious that the hearer will do in the normal course of events or of the hearer's own accord" (p. 66). Anchored in Brown and 
Levinson's (1987) politeness theory, requests are considered as the Face Threatening Acts (FTAs) as a speaker is imposing her/his will on the hearer (p. 65). Brown and Levinson (1987) suggested that when individuals are required to perform a face threatening act and they want to do it in a direct way, they should attempt to mitigate its threatening effect on the hearer's face.

Making requests is indivisible from politeness strategies because it asks for favor and does not threaten anybody. As Bialystok (1993) states, pragmatic requesting necessitates that the speaker has the ability to modify or soften the politeness level of the request appropriately based on the given situation. As such, speakers should vary the level of request's politeness by means of certain vocabularies or phrases which are perceived conventionally to reflect the respect for the hearer, like the word "please" or the phrase "would you mind". These linguistic elements are defined as mitigation devices and speakers utilize them to indicate the courtesy for the hearer (Blum-Kulka, House, and Kasper, 1989). Based on Alcón, Safont and Martínez-Flor (2005) classification, these mitigators are grouped into two types that is, internal which are lexical/syntactic items included inside the same request head act and external which are the items surrounded by the request head act. These politeness strategies and the way of employing them by learners for saving the face are of paramount importance in the success or failure of the communication ( Celce-Murcia \& Olshtain, 2000).

\subsection{Statement of the Problem}

The reason behind the selection of the speech act of request is rooted in the fact that possessing the impositive nature, this speech act requires the learners to have a good command of pragmatic knowledge or expertise and also the knowledge of how to mitigate it to lessen its impositive pragmatic force is necessary ( Trosborg, 1995; Sifianou, 1999). Moreover, request-making can be specifically hard task due to the complication of the elements linguistically utilized for conveying sociopragmatic meaning and the detaildness of the mitigators(politeness strategies). When people select inappropriate structures or strategies, it can further yield the socially/culturally inappropriate words or utterances and thus result in the pragmatic failure and the collapse in interaction. For example, a worker who makes the request from his boss with this utterance: Can I have a raise? can be considered as the direct request or even impolite request and thus be rejected by the boss.

Since this instance shows, inappropriate request may have the correct grammatical form but not pragmatically appropriate ( Cenoz, 2003; Thomas, 1983). Therefore, the evidence shows that the non-native speakers lack the sufficient pragmatic competence to produce appropriate utterances (Kasper and Rose 2002). This matter is better reflected in Schmidt's (1993) argument that the mere disposal to the features of the target language is not adequate for learners because pragmatic functions and pertinent features in context are not significant or obvious to learners and they do not pay attention to them after lengthy period of exposure to them. Therefore, these features should be taught to learners. Bardovi-Harlig (2001) and Bardovi-Harlig and Mahan-Taylor (2003) proposed the essentiality of L2 pragmatic instruction with this documentation that ESL learners who are not instructed in L2 pragmatics are different outstandingly from native speakers in producing and comprehending the pragmatic features in the second language ( Rose, 2005). As such, scholars in the domain of interlanguage pragmatics have stressed the significance of an explicit instruction to teach learners different pragmatic features and raise pragmatic awareness or consciousness in the secondlanguage ( Kasper and Roever, 2005; Rose, 2005; Bardovi-Harlig and Mahan-Taylor 2003; Eslami-Rasekh , 2005).

Furthermore, as Kasper (2001) stated, establishing the essential circumstances to promote pragmatic competence of learners is suggested in second language environments. In fact, the claim is in spite of the a lengthy duration of exposure with the second language, most of the pragmatic features are incomplete or not salient for learners regardless of all the merits that second language environment may have for the development of the pragmatic competence. Consequently, including pragmatics in second language classroom is essential because learners can perceive and understand the use of language appropriately and they can be equipped with the knowledge of a variety of language choices employed based on the situation and the hearer through instruction ( Bardovi-Harlig, 1996, 2001).

Despite ample evidence on the success of speech acts intervention in EFL contexts, there are noticeably inadequate studies in the context of ESL, demonstrating the need for further research (Kasper and Rose, 1999, 2002). This superiority of EFL to ESL in attracting pragmatic instruction confirms the ESL learners' need for authentic input.

While a host of studies have focused on the effects of instruction on the production of the L2 pragmatic features or their use in interaction, there is a paucity of study on the instructional effects on learners' pragmatic comprehension and needs to be considered in L2 pragmatics (Rose 2005). The exceptions are some studies done before like Bouton (1994a) and Kubota (1995) studies regarding the comprehension of implicatures in indirect 
responses by ESL learners. More studies should be done on the comprehension of the pragmatic features. In addition, most studies have included intermediate and advanced learners and postgraduate students; there is a dearth of studies on undergraduate students (Rose, 2005).

Since many students in Malaysian universities are undergraduates and the lack of interventional studies is witnessed in ESL contexts, it is, therefore, worth investigating the teaching of pragmatic routines such as requests to this group of students. So, this paper generally aims to enhance the interventional pragmatic studies available and boost the request speech act in particular by addressing the following research question: What are the impacts of explicit form-focused teaching on Malaysian undergraduate students in terms of producing and comprehending polite requests in English?

Classroom interventional instruction has drawn much attention in pragmatic studies in general and speech acts domain in particular. Studies show the language learners' pragmatic knowledge can positively be affected and hence developed irrespective of the learners' background in language or culture and when students intentionally notice the linguistic features of L2, they can develop their pragmatic knowledge much better. So it is the job of the instructors to augment the L2 pragmatic awareness of students in general and speech acts in particular (Schmidt, 1993). Therefore, a large number of interventional pragmatic studies have supported the standpoint towards the explicit instruction of L2 pragmatics (Takimoto, 2009).

Fukuya and Clark (2001) focused on the ESL setting, zooming in on requests through an explicit pragmatic instruction. In their study, there were 34 adult ESL students in three groups: the first group was a Focus on Form group. Through audiovisual scenarios, they received typographical enhancements of mitigators. The second group called Focus on Form watched an explicit version of the instruction on mitigators through extra input enhancement. The control group was the third group. For the assessment of the development in both experimental groups, a pragmatic test and a multiple choice listening comprehension were used. The findings definitely did not indicate which treatment succeeded in yielding six different request formulations (i.e. I know, but; I was wondering if; I'd appreciate it if; I'd be grateful if; possibly; perhaps). It is claimed that the inconclusiveness of the results was mostly owing to the low sample size, shortness treatment period, and post test design.

Studying Irish learners of German in terms of their pragmatic development, Barron (2003) found out certain conditions should be fulfilled for positive results . It was found that learners need to receive adequate explicit input. They also need to saliently notice the gaps which exist between the L2 output and their own interlanguage.

Bardovi-Harlig and Griffin (2005) did the study to investigate L2 pragmatic awareness of ESL learners through an awareness-raising activity before they wre instructed formally in the domain of pragmatics. The participants were 43 students with 18 language backgrounds from five intact ESL classes. For identifying the pragmatic infelicities the learners worked in pair group in scenarios which were recorded during the activity and they role played in order to remedy the infelicities identified. These role-plays were also recorded by video. The role-plays were aimed to determine the kind of pragmatic infelicities noticed and modified by learners. The results of role-plays illustrated that despite the differences in the form and content of remedies from the norms of the second language; the learners could identify and make the missing speech acts and semantic formulas. Therefore, the finding of this study is suggestive of the benefit of instruction on learners' performance.

Suh (2009) investigated the effect of metapragmatic instruction by combining explicit teaching, activities for raising the awareness, and guided practice to teach how to make request. The participants included twelve intermediate-advanced ESL Somalis and Mexicans. A pre-test post-test design used in the study. A Written Discourse Completion Task (DCT) and a course evaluation open-ended questions with 15-item were utilized as the data collection instruments. The results suggest that the explicit instruction had some positive impacts on participants' responses in making request in post-test compared to pre-test.

Taking into account the impacts of teaching pragmatic features on the awareness and development of learners' ESL pragmatics, most instructors' experience and observation in Malaysian undergraduate programs confirm the undergraduate students' need for L2 pragmatic strategies in order to overcome their communication problems inside and outside the classroom. This study is a response to such a need. It investigated the impacts of intervention on students' performance of making requests in English.

\section{Method}

\subsection{Participants}

The participants included 60 Malaysian undergraduate students, had studied English from the primary school, had Malay as their first language, and were in 18-22 age range. They had chosen from an English spoken course. 
They were grouped into two (treatment group and control group). They did not know that they would receive instruction on English lexical and syntactic downgraders.

\subsection{Instructional Treatment}

Hill (1997) and Takahashi $(1998,2001)$ did similar studies to learner's request strategies in which they found how the speech act of request in the target language can be downgraded and made more polite and formulaic via the employment of syntactic downgraders including aspect and tense and words and phrases to downgrade the threatening effect ( lexical/phrasal downgraders) such as subjectivizers and downtoners as formulaic politeness strategies. Accordingly, the focus of this study was on the explicit instruction of two lexical/phrasal downgraders, downtoners and subjectivizers, and two syntactic downgraders, aspect and tense in English requests. Lexical/phrasal downgraders mitigate the imposition of a request force through modification of the Head act internally by means of lexical/phrasal selection, while syntactic downgraders soften the imposition of Head Act internally though the mitigation of the imposition of the request force by means of syntactic choices ( Blum-Kulka, House and Kasper 1989).

\subsection{Instruments and Data Collection Procedure}

The study utilized a pre-test post-test paradigm to examine the impact of form-focused teaching on learners' ability in comprehending and producing politeness strategies in making requests in English. Three tests were utilized in this study: discourse completion test, listening test and an acceptability judgment test including many situations with one speech act (request). The discourse completion test, listening test and an acceptability judgment test included 20 scenarios, while the LT comprised 15 ones. All scenarios included the speech act of request, and three social factors were considered in the questionnaires: power (the position of the speaker with regard to the hearer), amount of imposition (the burden of the request and the performance of it by the), and social distance (the closeness/intimacy between the speaker and the hearer). There correlational relationship exists between the level of imposition and the employment of downgraders. It means that that a higher level of imposition, along with social power and social distance, yields the employment of further downgraders. As a result, this investigation concentrates on items with high imposition associated with social power and social distance. An example item is illustrated below; it may be categorized as [+imposition], [.power], [+distance], where [+] means "more" and [.] means "less." The three tests are explained in more details below.

You are writing a difficult paper for Professor Hill. You need some help with the paper but Professor Hill is away for a month. A friend of yours has suggested you go and see Professor Watson. Although you do not know Professor Watson and Professor Watson is extremely busy, you have decided to ask Professor Watson to look through your long paper before you hand it in the next day. What would you ask Professor Watson? (based on Takahashi, 1998, 2001).

Open-ended Discourse Completion Test (OPDCT). In this type of test, the students were required to read 20 scenarios and reply what they verbally say in each scenario. All the items were all in English language. The students did not have any time limit to answer the items but most of them took 30-45 minutes to complete the test. The Mean and Standard Deviation were considered as the difference in the pre-tests to post-tests performance.

Listening Test (LT). The listening test included 15 scenarios and the participants were required to listen to a dialog between some people (a non-native university student and English native speakers) and then to determine the appropriate answer from the students by means of a six-point Likert scale. If the students chose 0 , it means that the item was not appropriate at all and if they opted out 5 , it means that the request form is completely appropriate. There was a time limit of two to three seconds for scoring of each request form. The scoring was based on baseline data from native speakers. The scores given to students were either 0 or 5 .

Acceptability Judgment Test (AJT). Based on this test, the subjects were asked to read 20 scenarios. After that, they were provided with 11 request forms and they were told to rate the most appropriate (the first possible answer) on a Likert scale consisting of 11 points and then to rate the subsequent appropriate answers based on their degree of acceptability as other correct responses. In this test, 0 means that the answer was not appropriate at all and 10 means that the response was totally appropriate. According to Hatch and Lazartan (1991), a wider range in scale necessitates more precision in judgments by the respondents. As such, this study made use of 11-point Likert scale test. Like the listening test, the subjects got either 0 or 5 points and the partial points were not assigned to the students.

The pre-test was administered five days before the intervention and the post-test immediately after the treatment. The tests were in three formats: completion test, listening test and an acceptability judgment test adopted from 
Takahashi (2001). These tests included many situations with one speech act (request). The situations were validated by Hudson, Detmer, and Brown (1992, 1995), Hill (1997), and Takahashi (1998, 2001), they were revised to include a variety of situations pertinent to two settings: student's life inside and outside the educational settings. Two versions (A and B) of the above tests were made, and were all adapted to present the same conditions across the pre-test and post-test meetings. Each instructional session lasted for 30 minutes and run twice a week for 6 weeks by the same English spoken course instructor at the University.

Table 1. Cronbach alpha reliability estimates for each test

\begin{tabular}{lll}
\hline Test & Version A & Version B \\
\hline Open-ended completion test (Takahashi, 2001) & .942 & .919 \\
Listening test & .791 & .714 \\
An acceptability judgment test & .868 & .858 \\
\hline
\end{tabular}

Cronbach alpha reliability estimates were used to calculate the reliability of each test (see Table 1). It shows, Cronbach alpha is between 0 and 1 . In most practical research, alpha 0.65 or higher index is illustrative of acceptable reliability. In this research, standard alpha illustrates high reliability of each test.

\section{Results and Discussions}

A descriptive statistics for quantitative variables was gained to show the resulting data on minimum and maximum scores, sum, mean, standard deviation, and variance of the scores and the mean performances in pre-test and post-test in control and experimental groups. Table 2 shows the comparison of the means of marks by the experimental and control groups on the pre-test and post-test. It indicates the mean score of experimental group is 4.05 and control group is 4.34 . The mean in two groups is nearly at the same level.

Table 2. Descriptive statistics for two groups in pre-test and post-test

\begin{tabular}{llllll}
\hline Group & & $\mathrm{N}$ & Mean & $\mathrm{SD}$ \\
\hline Pre-test & Experimental & 30 & 4.05 & 1.371 \\
& Control & 30 & 4.34 & 1.348 \\
\multirow{3}{*}{ Post-test } & Experimental & 30 & 6.10 & 1.913 \\
& Control & 30 & & 2.85 & 1.163 \\
& & Mean Differences & df & $\mathrm{t}$ & Sig(2-tailed $)$ \\
Post-test & & 3.43 & 49 & -7.477 & 0.00 \\
\hline
\end{tabular}

Considering the alpha level of 0.05 , the effect of form-focused intervention on students' comprehension and production of polite requests in English is statistically significant, $t(48)=-7.477, p=0.00$. The results display that the treatment group learned during the pre-tests to the post-tests and it confirms the effect of instruction on students' performance.

Based on the fact, such tests are greatly dependent on working memory and the learners must effectively and rapidly reply to the stimuli. In the deductive intervention, the learners explicitly faced the information, while in the inductive intervention they should do the discovery of the rules from the examples. The learners could not strongly form the explicit knowledge in the deductive intervention whereas in the inductive intervention the participants did. Additionally, the participants using the inductive approach succeeded in handling and storing information about the pragmatic features in their working memory. Hence, the inductive instruction was effective regarding the structured input tasks or problem-solving tasks.

In addition, this study showed that practice via input-based instruction can boost the learners' command of comprehending and producing the pragmatic forms/ structures. This finding is in line with the popular theory of information-processing claiming that the input-focused instruction can develop the ability or capability in learners in terms of the comprehension and production of the second language features by use of similar information source underlying it. Based on Robinson's (1995) contention of this theory, the function of cognitive mechanism is processing the information in the input to represent the target structures or forms mentally (in the mind). The accessibility of this knowledge is by means of other cognitive mechanism and at last it develops the learners' ability for the comprehension nad production of target features.

The findings of this study is in agreement with other studies such as Olshtain and Cohen (1990), Billmyer (1990a,b), Bouton (1994a), Lyster (1994) study on hedging devices, Wishnoff (2000), Yoshimi (2001), Rose and 
$\mathrm{Ng}$ (2001), Takahashi (2001), Liddicoat and Crozet (2001), Safont (2003), but they contradict with the findings of other studies which showed that treatment or instruction had a little or no effect on participants' performance during the pre-test to post-test such as Locastro ( 1997) which did not find any change after the duration of 9 weeks of teaching the mitigating devices and participants just made use of the head acts in the post-test and no significant effect was observed from the pre-test to the post-test. Fukaya and Clark (2001), Tateyama (2001) and Salazar (2003) had the same results.

Finally, as the whole, the overall results of the interventional investigations on the impact of teaching agree totally with this research suggesting that with no instruction in pragmatic features and functions, learners do not gain adequate ability and knowledge in an assortment of pragmatic domains ( Bardovi-harlig, 2001).

\section{Conclusion}

This study showed that practice via input-based instruction can boost learners' command of comprehending and producing target structures coincides with the information-processing theory claiming the input-oriented instruction can help learners to develop the ability and knowledge of comprehending and producing the second language pragmatic features with the use of the similar sources of knowledge underlying it (Robinson, 1995).

What this study has observed is that there is merit in teaching formulaic request strategies in a language classroom. The results confirmed the positive effects of instruction on students' performance with statistically significant results and it can suggest the likelihood of a useful teaching technique in promoting the awareness of formulaic politeness strategies in educational contexts.

This study has some limitations that should be noticed by future studies. First, the number of the participants was low and it may have some effects on the overall results. Second, the time duration for the instruction of the politeness strategies may be better to increase because by the increase in the instruction time, students can receive more input and also feedback and it can have better effects on their performance.

Even with bearing such limitations in mind, this research has some contributions to our knowledge that explicit teaching of target language pragmatic features and functions results in a positive results and students' gains in this domain, especially in second language environments such as Malaysia in spite of the public belief regarding its richness to exposure with the target language in comparison with the foreign language contexts.

\section{Acknowledgements}

I would like to thank Universiti Kebangsaan Malaysia in providing funds for this project (Research Code: UKM-PTS-2011-090)

\section{References}

Alcón, E., Safont, P., \& Martínez-Flor, A. (2005). Towards a typology of modifiers for the speech act of requesting: A socio-pragmatic approach. RceL, Revista Electrónica de Lingüistica Aplicada, 4, 1-35.

Bachman, L. F. (1990). Fundamental Considerations in Language Testing. Oxford: Oxford University Press.

Bardovi-Harlig, K. (1996). Pragmatics and language teaching: Bringing pragmatics and pedagogy together. In L. F. Bouton (Ed.), Pragmatics and Language Learning (Vol. 7). Urbana, IL: University of Illinois at Urbana-Champaign.

Bardovi-Harlig, K. (2001). Empirical evidence of the need for instruction in pragmatics. In K. R. Rose, \& G. Kasper (Eds.), Pragmatics in Language Teaching. Cambridge: Cambridge University Press. http://dx.doi.org/10.1017/CBO9781139524797.005

Bardovi-Harlig, K., \& Mahan-Taylor, R. (2003). Teaching Pragmatics. Washington DC: U.S. Department of State Office of English Language Programs. Retrieved from http://exchanges.state.gov/education/engteaching/pragmatics.htm

Barron, A. (2003). Acquisition in Interlanguage Pragmatics: Learning How to Do Things with Words in a Study Abroad Context. Benjamins, Amsterdam.

Bialystok, E. (1993). Symbolic representation and attentional control in pragmatic competence. In G. Kasper, \& S. Blum-Kulka (Eds.), Interlanguage pragmatics (pp. 43-63). New York: Oxford University Press.

Blum-Kulka, S., House, J., \& Kasper, G. (1989). Investigating cross-cultural pragmatics: An introductory overview. In S. Blum-Kulka, J. House, \& G. Kasper (Eds.), Cross-cultural pragmatics: Requests and apologies (pp. 1-36). Norwood, NJ: Ablex. 
Brown, P., \& Levinson, S. (1978). Universals in language use: Politeness phenomena. In E. N. Goody (Ed.), Questions and Politeness: Strategies in Social Interaction. Cambridge: Cambridge University Press.

Brown, P., \& Levinson, S. C. (1987). Politeness: Some universals in language usage. Cambridge University Press, Cambridge.

Celce-Murcia, M., \& E. Olshtain. (2000). Discourse and Context in Language Teaching. A Guide for Language Teachers. Cambridge: Cambridge University Press.

Celce-Murcia, M., Dörnyei, Z., \& Thurrell, S. (1995). Communicative competence: A pedagogically motivated model with content specifications. Issues in Applied Linguistics, 6, 5-35.

Cenoz, J. (2003). The intercultural style hypothesis: L1 and L2 interaction in requesting behaviour. In V. Cook (Ed.), Effects of the second language on the first (pp. 62-80). Clevedon, UK: Multilingual Matters.

Eslami-Rasekh, Z. (2005). Raising the pragmatic awareness of language learners. ELT Journal, 59, 199-208. http://dx.doi.org/10.1093/elt/cci039

Fraser, B. (1980). Conversational mitigation. Journal of Pragmatics, 4, 341-350. http://dx.doi.org/10.1016/0378-2166(80)90029-6

Fraser, B. Rintell, E., \& Walters, J. (1980). An approach to conducting research on the acquisition of pragmatic competence in a second language. In D. Larsen-Freeman (Ed.), Discourse analysis in second language acquisition (pp. 3-20). Rowley: Newbury House.

Fukuya, Y. J., Clark, M. K. (2001). A comparison of input enhancement and explicit instruction of mitigators. In Bouton, L. (Ed.), Pragmatics and Language Learning (Vol. 10). University of Illinois at Urbana-Champaign, Urbana.

Hee, K. K. (2007). The role of the learner subjectivity and pragmatic transfer in the performance of request by Korean ESL learners. Unpublished doctoral dissertation, Texas A \&M University.

Hill, T. (1997). The development of pragmatic competence in an EFL context. Unpublished doctoral dissertation, Temple University, Japan.

Hudson, T., Detmer, E., \& Brown, J. D. (1992). A framework for testing cross-cultural pragmatics. Honolulu, HI: University of Hawai'i Press.

Hudson, T., Detmer, E., \& Brown, J. D. (1995). Developing prototypic measures of cross-cultural pragmatics. Honolulu, HI: University of Hawai'i Press.

Ishihara, N., \& Cohen, A. (2010). Teaching and learning pragmatics: Where language and culture meet. Longman, Harlow.

Kasper, G. (2001). Classroom research on interlanguage pragmatics. In K. Rose, \& G. Kasper (Eds.), Pragmatics in language teaching (pp. 33-62). Cambridge: Cambridge University Press. http://dx.doi.org/10.1017/CBO9781139524797.006

Kasper, G., \& Roever, C. (2005). Pragmatics in second language learning. In E. Hinkel (Ed.), Handbook of Research in Second Language Teaching and Learning. Mahwah, New Jersey: Lawrence Erlbaum Associates.

Kasper, G., \& Rose, K. (1999). Pragmatics and second language acquisition. Annual Review of Applied Linguistics, 13, 215-247.

Kasper, G., \& Rose, K. (2002). Pragmatic development in a second language. Blackwell, Oxford.

Koike, D. A. (1989). Pragmatic competence and adult L2 acquisition: Speech acts in interlanguage. Modern Language Journal, 73, 281-289. http://dx.doi.org/10.1111/j.1540-4781.1989.tb06364.x

Kubota, M. (1995). Teachability of conversational implicature to Japanese EFL learners. IRLT Bulletin, 9, 35-67.

Liddicoat, A. J., \& Crozet, C. (2001). Acquiring French interactional norms through instruction. In K. R. Rose, \& G. Kasper (Eds.), Pragmatics in Language Teaching. Cambridge: Cambridge University Press. http://dx.doi.org/10.1017/CBO9781139524797.012

Lyster, R. (1994). The effects of functional-analytical teaching on aspects of French immersion students' sociolinguistic competence. Applied Linguistics, 15, 263-287. http://dx.doi.org/10.1093/applin/15.3.263

Olshtain, E., \& Cohen, A. D. (1991). Teaching speech act behavior to nonnative speakers. In M. Celce-Murcia (Ed.), Teaching English as a Second or Foreign Language. Boston: Heinle and Heinle. 
Robinson, P. (1995). Attention, memory, and the "noticing" hypothesis. Language Learning, 45, 283-331. http://dx.doi.org/10.1111/j.1467-1770.1995.tb00441.x

Rose, K. R., \& Hg Kwai-fun, C. (2001). Inductive an deductive teaching of compliments and compliment responses. In K. R. Rose, \& G. Kasper (Eds.), Pragmatics in Language Teaching. Cambridge: Cambridge University Press.

Rose, K. R., \& Kasper, G. (Eds.). (2001). Pragmatics in Language Teaching. Cambridge University Press, Cambridge. http://dx.doi.org/10.1017/CBO9781139524797

Safont-Jorda, M. (2003). Instructional effects on the use of request acts modification devices by EFL learners. In A. Martinez Flor, E. Uso Juan, \& A. Fernandez Guerra (Eds.), Pragmatic competence and foreign language teaching (pp. 211-232). Castello de la Plana, Spain: Publicacions de la Universitat Jaume.

Schmidt, R. (1993). Consciousness, learning and interlanguage pragmatics. In Kasper, G., \& Blum-Kulka, S. (Eds.), Interlanguage Pragmatics (pp. 21-42). Oxford University Press, New York.

Searle, J. R. (1969). Speech acts: An essay in the philosophy of language. Cambridge: Cambridge University Press. http://dx.doi.org/10.1017/CBO9781139173438

Sifianou, M. (1999). Politeness Phenomena in England and Greece. A Crosscultural Perspective. Oxford: Oxford University Press.

Takahashi, S. (1998). Quantifying requestive imposition: Validation and selection of situation for L2 pragmatic research. Studies in Languages and Cultures, 9, 135-159.

Takahashi, S. (2001). The role of input enhancement in developing interlanguage pragmatic competence. In K. Rose, \& G. Kasper (Eds.), Pragmatics in language teaching (pp. 171-199). New York: Cambridge University Press. http://dx.doi.org/10.1017/CBO9781139524797.014

Tateyama, Y. (2001) Explicit and implicit teaching of pragmatics routines: Japanese sumimasen. In K. R. Rose, \& G. Kasper (Eds.), Pragmatics in language teaching (pp. 200-222). Cambridge: Cambridge University Press. http://dx.doi.org/10.1017/CBO9781139524797.015

Thomas, J. (1983). Cross-cultural Pragmatic Failure. Applied Linguistics, 4, 91-112. http://dx.doi.org/10.1093/applin/4.2.91

Trosborg, A. (1995). Interlanguage Pragmatics: Requests, Complaints and Apologies. Berlin: Mouton de Gruyter. http://dx.doi.org/10.1515/9783110885286

Usó-Juan, E., \& Martínez-Flor, A. (2006). Approaches to language learning and teaching: Towards acquiring communicative competence through the four skills. In E. Usó-Juan, \& A. Martínez-Flor (Eds.), Current Trends in the Development and Teaching of the Four Language Skills. Berlin: Mouton de Gruyter. http://dx.doi.org/10.1515/9783110885286

Wishnoff, J. (2000). Hedging your bets: L2 learners' acquisition of pragmatic devices in academic writing and computer-mediated discourse. Second Language Studies, 19. Retrieved from http://www.hawaii.edu/sls/uhwpesl/on-line_cat.html

Yoshimi, D. R. (2001). Explicit instruction and JFL learners' use of interactional discourse markers. In K. R. Rose, \& G. Kasper (Eds.), Pragmatics in Language Teaching. Cambridge: Cambridge University Press. http://dx.doi.org/10.1017/CBO9781139524797.016 